\title{
Population structure of Hirundichthys oxycephalus in the northwestern Pacific inferred from mitochondrial cytochrome oxidase I gene
}

\author{
Chang-En Chou ${ }^{1 \dagger}$, Te-Yu Liao $^{2 \dagger}$, Hsueh-Wen Chang ${ }^{1 *}$ and Shui-Kai Chang ${ }^{3 *}$
}

\begin{abstract}
Background: Hirundichthys oxycephalus is an important flyingfish resource in eastern Taiwan and northwestern Japan. A substantial catch decline in Taiwan has caused serious concerns on stock status of the fish, prompting the government to impose a set of regulations on flyingfish egg fishery since 2008. However, the regulations were set in a precautionary manner, without considering the fundamental understanding of the population genetic structure. This study aims to investigate the population genetic structure of $H$. oxycephalus in the region based on mtDNA cytochrome oxidase I (COI) gene and to thus provide scientific information for sustainable management of the resource.
\end{abstract}

Results: Tissue samples (156) from six localities of eastern Taiwan and western Japan were collected, and 616 bp of mtDNA COI gene were sequenced. Seventy haplotypes were determined, and the haplotype diversity and nucleotide diversity were estimated as $0.93 \%$ and $0.57 \%$, respectively. Results of various statistical analyses suggested that the genetic differentiations among the six localities were small and most variation occurred within populations, indicating a high gene flow in the region with undergoing population expansion. Although the study showed that the fishes were genetically divided into two groups, the support was low and the separation was not geologically evident.

Conclusions: The study revealed two groups of $\mathrm{H}$. oxycephalus in the northwestern Pacific Ocean. However, due to high gene flow, an association of either group to a spatial distribution was not observed, and so the two groups may be considered as one population. Thus, the results favored the conclusion that $\mathrm{H}$. oxycephalus from eastern Taiwan and western Japan belong to the same population and, consequently, that the management unit of the current regulations only covering eastern Taiwan does not match the spatial structure of the population. Rather, the results suggest that joint efforts from countries within the population boundary are necessary to maintain a sustainable exploitation.

Keywords: Ecological population; Flyingfish; Taiwan; Northwestern Pacific; COI

\section{Background}

The flyingfish family Exocoetidae is a group of small fish comprising 52 species and is distributed globally in the tropical and subtropical areas of three oceans (Nelson 2006; Chang et al. 2012a; Xu et al. 2013). Exocoetids are

\footnotetext{
* Correspondence: hwchang@mail.nsysu.edu.tw; skchang@faculty.nsysu.edu.tw ${ }^{\dagger}$ Equal contributors

${ }^{1}$ Department of Biological Sciences, National Sun Yat-sen University, 70, Lien-hai Road, Kaohsiung 804, Taiwan

${ }^{3}$ Institute of Marine Affairs, National Sun Yat-sen University, 70, Lien-hai Road, Kaohsiung 804, Taiwan

Full list of author information is available at the end of the article
}

low-tropical level species (Wu et al. 2010) and are a food source for dolphinfish, tuna, and swordfish (Oxenford and Hunte 1999; Wu et al. 2006). They are known as flyingfish due to their ability to glide in the air over the water using large and elongated pectoral and asymmetric caudal fins (Davenport 1994). This uncommon flying behavior serves as an escape mechanism from predators and is uniquely present in extant fish species of the Exocoetidae group as a homoplasy of the extinct family Thoracopteridae (Davenport 1994; Kutschera 2005; Xu et al. 2013).

The flyingfish is economically important in the Caribbean and the western Pacific Ocean (Rennie 2002; Potts et al. 
2003). It is the national fish and one of the national cuisines of Barbados (Cumberbatch and Hinds 2013) and provides a commercially important harvest in Japan, especially in the southwestern regions (Masuda et al. 1984). In Taiwan, it supports the stability of the Kuroshio ecosystem as an intermediary in the bioenergetics transfer, the sustainability of artisanal fisheries as a locally consumed dish and major bait for fishing, and the continuity of aboriginal Tao culture as a respectable emblem (Chang et al. 2012a).

At least 29 species of flyingfish in seven genera are reportedly found in the waters off Taiwan and adjacent areas (Chang et al. 2012a). Among these, Hirundichthys oxycephalus (bony flyingfish) is one of the dominant flyingfishes in the Kuroshio Current (Chang et al. 2012b). The fish can be found from south of Taiwan to northwestern Japan (Ichimaru 2007; Chang et al. 2012b); however, it has not been found in the Philippines according to a 3-year sampling program conducted in Batanes (SK Chang and $\mathrm{CH}$ Lin, unpublished data). The fish was utilized as the main source of eggs for flyingfish egg fisheries in northern Taiwan and the bait of longline and troll fisheries in eastern Taiwan (Chang et al. 2012a, b). Juveniles of the fish also constituted an important target of boat seine and setnet fisheries in northwestern Japan (Ichimaru 2007). A decline of more than $60 \%$ in catches of the fish and its eggs occurred in Taiwan during the 2006 to 2007 period (Fisheries Agency 2010). This decline has caused serious concerns regarding the fish stock status and prompted the Taiwan government to implement a set of regulations on flyingfish egg fishery since 2008, including an annual catch limit. The catch limit regulation is precautionary, however, and has no scientific support regarding the optimal fish stock abundance or, more basically, on the boundary of the fish population that is crucial for effective fishery management (Garcia 2005). Therefore, the population structure of $H$. oxycephalus needs to be resolved urgently in order to confirm if the population is trans-boundary and is exploited by more than one country.

Genetic analysis is a useful tool for species identification and the determination of population structure which could provide a scientific basis for fishery management (Ward 2000). The technique has been successfully utilized for the sustainable management of many economically and ecologically important fish, such as albacore and bigeye tunas (Ward 2000). For flyingfish, the molecular phylogeny of selected species of the Exocoetidae group has been reconstructed based on the mitochondrial cytochrome $b$ and the nuclear RAG2 genes (Lewallen et al. 2011). Other than this exception, research on population genetics of flyingfish is rare and previous studies all focused on Hirundichthys affinis (Gomes et al. 1998; Gomes et al. 1999, 2000). This is the first study that aims to investigate the population structure of $H$. oxycephalus in the northwestern Pacific Ocean inferred from mitochondrial cytochrome oxidase I (COI), and to provide a scientific basis for proper fishery management.

\section{Methods}

From 2008 to 2011, samples of H. oxycephalus were collected from four localities along the eastern coasts of Taiwan, including Keelung (KL), Yilan (YL), Hualien (HL), and Ludao (LD), as well as two localities along the northwestern coasts of Japan, including Nagasaki (NS) and Yakushima (YS). Tissue samples were obtained from 150 adult fish caught by drive-in net, gillnet, and setnet in the six localities, four juveniles from $\mathrm{KL}$, and two eggs from YL using hand-held net (Figure 1 and Table 1). Tissue samples were stored frozen at $-20^{\circ} \mathrm{C}$ before the extraction of DNA.

\section{DNA sequencing}

Crude DNA was extracted from the muscle tissue by proteinase K using a Wizard Genomic DNA Purification Kit (Promega, Madison, WI, USA). The mitochondrial COI gene was amplified with the following two primers (Ward et al. 2005): FishF1 (5'TCAACCAACCACAAA GACATTGGCAC3') and FishR1 (5'TAGACTTCTGGG TGGCCAAAGAATCA3'). PCR was performed using a GeneAmp PCR System 2400 thermal cycler (Applied Biosystems, Carlsbad, CA, USA) with an initial denaturation at $95^{\circ} \mathrm{C}$ for $4 \mathrm{~min}$, followed by 35 cycles of amplification (denaturing at $94^{\circ} \mathrm{C}$ for $0.5 \mathrm{~min}$, annealing at $55^{\circ} \mathrm{C}$ for $0.5 \mathrm{~min}$, and extension at $72^{\circ} \mathrm{C}$ for 50 seconds) and a final extension at $72^{\circ} \mathrm{C}$ for $10 \mathrm{~min}$. Autosequencing was performed on ABI 3100 Avanter Genetic Analysis with an ABI PRISM BigDye ${ }^{\mathrm{mx}}$ Terminators v 2.0 Cycle Sequence Kit (Applied Biosystems, Carlsbad, CA, USA). The sequences were double checked with forward and reverse strands.

\section{Sequences analysis}

All sequences were checked visually and aligned with Clustal W Multiple Alignment using Bioedit 7.1.3 (Hall 1999). Genetic distances were calculated using the Kimura 2-parameter model as suggested by MEGA 5.02 (Tamura et al. 2011).

A minimum spanning network was constructed using the Arlequin 3.5.1.3 program (Excoffier and Lischer 2010). In order to measure genetic variation, haplotype diversity $(h)$ and nucleotide diversity $(\pi)$ were calculated. In order to estimate the nucleotide differences between populations, the $\mathrm{Nm}$ and fixation indexes $(F$ st) were calculated. All of the above indices were calculated by DNASP v5. To analyze if the flyingfish from Taiwan and Japan are from the same population, all samples were hierarchically clustered into Taiwan and Japan groups. 


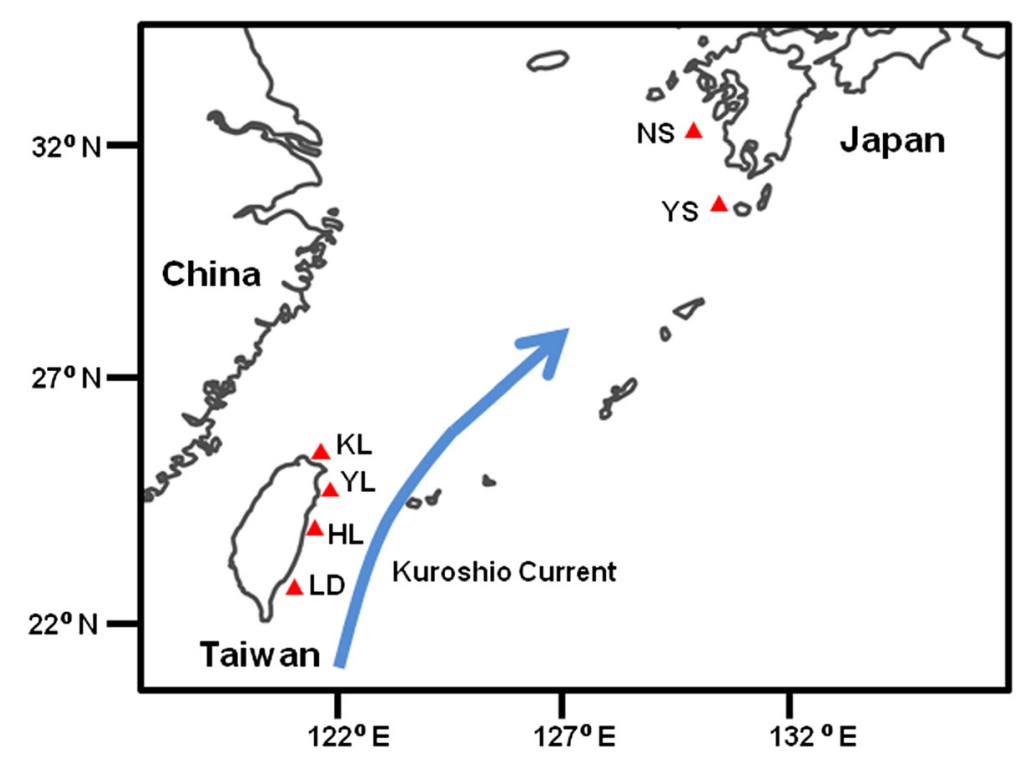

Figure 1 Sampling localities of Hirundichthys oxycephalus from the northwestern Pacific Ocean. NS, Nagasaki; YS, Yakushima; KL, Keelung; YL, Yilan; HL, Hualien; LD, Ludao.

Then, a nested analysis of molecular variance (AMOVA) (Excoffier et al. 1992) was performed using Arlequin to estimate population differentiation from the genetic variation of each hierarchical level. Furthermore, neutrality tests, including Tajima's $D$, a frequency-based test to identify the genes under selection (Tajima 1989), and Fu's Fs (Fu 1997), a test sensitive to population demographic expansion, were performed using Arlequin. Mismatch distribution was analyzed to examine the model of sudden population expansion (Harpending 1994). Demographic history and the divergence time for the $H$. oxycephalus $\mathrm{COI}$ sequence were further estimated using Bayesian evolutionary analysis sampling trees (BEAST) ver. 1.6.2 (Drummond and Rambaut 2007). Bayesian skyline analysis (which was calculated using BEAST) was used to infer the changes in effective population size
(Ne) across time. The analysis was run with 50 million steps in a Markov chain Monte Carlo (MCMC) simulation under the HKY + I model, relaxed molecular clock model (uncorrelated log-normal), and 1.2\% nucleotide substitution rate (Bermingham et al. 1997). Other operators were optimized automatically. BEAST under the Yule process model was also used to estimate the time to the most recent common ancestor (TMRCA). The other model parameters were the same with Bayesian skyline analysis. The results were viewed using Tracer v1.5 (Rambaut and Drummond 2003).

Exocoetus volitans was designated as an out-group for tree rooting. In addition to $H$. oxycephalus, Cypselurus poecilopterus was included in all molecular analyses. An NJ tree was reconstructed with a Kimura 2-parameter model using MEGA 5.02 (Tamura et al. 2011). Bayesian

Table 1 Summary of genetic diversity indices of Hirundichthys oxycephalus samples from the northwestern Pacific Ocean

\begin{tabular}{lllllllll}
\hline Code & Locality & $\boldsymbol{N}$ & $\boldsymbol{h}$ & $\boldsymbol{\pi}$ & Tajima's $\boldsymbol{D}$ & Fu's Fs & SSD \\
\hline NS & Nagasaki & 54 & 0.90 & 0.0054 & $-1.5788^{*}$ & $-15.5619^{*}$ & 0.0220 & RI \\
YS & Yakushima & 8 & 1.00 & 0.0056 & $-1.5649^{*}$ & $-5.0985^{*}$ & 0.0541 & 0.0450 \\
KL & Keelung & 41 & 0.87 & 0.0060 & -1.4178 & $-14.1934^{*}$ & 0.0058 \\
YL & Yilan & 7 & 1.00 & 0.0063 & -1.4463 & $-3.6463^{*}$ & 0.0330 & 0.0305 \\
HL & Hualien & 12 & 0.92 & 0.0052 & -0.7891 & -2.3297 & 0.0075 & 0.0192 \\
LD & Ludao & 34 & 0.96 & 0.0055 & $-1.8500^{*}$ & $-22.9093^{*}$ & $0.0474^{*}$ & 0.1837 \\
Group I & & 112 & 0.93 & 0.0039 & $-2.3552^{*}$ & $-26.9307^{*}$ & 0.0008 & 0.0434 \\
Group II & & 44 & 0.54 & 0.0018 & $-2.4259^{*}$ & $-14.0031^{*}$ & 0.0022 & 0.0624 \\
Total & & 156 & 0.93 & 0.0057 & $-2.1052^{*}$ & $-26.0292^{*}$ & 0.0076 & 0.0221 \\
\hline
\end{tabular}

${ }^{*} p<0.05$. 
analysis was conducted using MrBayes v3.1.2 (Ronquist et al. 2012) with the GTR + I + G model as suggested by MrModeltest (Nylander 2004) and partitions based on codon position (first, second, and third). All parameters, with the exception of topology and branch length, were allowed to vary independently with sampling for 27 million generations (two concurrent analyses, $n$ runs $=2$; three heated chains, $n$ chains $=4$; chain temperature 0.1 ; sample frequency 1,000; burn in $=7$ million generations). Convergence was checked using the software Tracer v1.5 (Rambaut and Drummond 2003) as well as the SUMP and PLOT commands of MrBayes. Maximum parsimonious analysis was analyzed using TNT (Goloboff et al. 2008) by the heuristic algorithm with zero-length branches permitted. Reliability of NJ and MP trees were examined by bootstrapping with 1,000 replications (Felsenstein 1985) using MEGA 5.02 and TNT, respectively. Bayesian posterior probability was calculated by using the MCMC method with MrBayes v3.1.2.

\section{Results}

A total of 616 bp of mtDNA COI gene were sequenced from the $156 \mathrm{H}$. oxycephalus tissue samples. There are 62 variable sites, including 28 parsimoniously informative sites and 34 singletons. The mean nucleotide diversity $(\pi)$ is $0.57 \%$, with values ranging from $0.52 \%$ for $\mathrm{HL}$ to $0.63 \%$ for YL (Table 1 ). Seventy haplotypes were determined, and the mean haplotype diversity for all samples is 0.93. Two of them were found in almost every locality in Taiwan and Japan. Furthermore, they were shared by $37 \%$ of the total individuals; 13 haplotypes were shared by at least two localities and $28 \%$ of the total individuals; and the remaining 55 haplotypes were found in only one locality. The frequency is $35 \%$ of the total individuals. The overall mean genetic distance of $H$. oxycephalus is $0.58 \%$. The minimum spanning network of all samples revealed two distinct groups. Group I comprises most samples (71\%) collected from all localities, while group II was smaller (29\%) and comprised of samples from all localities except YS (Figure 2A).

All $15 \mathrm{Fst}$ values for the six localities were smaller than 0.15 ; more than half of them (8) were 0 , indicating high gene flow of $H$. oxycephalus in the northwestern Pacific Ocean. The AMOVA results (Table 2) did not show differentiation between Taiwan (HL, KL, LD, and YL) and Japan (NS and YS; $\Phi C T=-0.0306, p=0.1$ ), and the variation was $-3.0613 \%$. Most variation was within populations $(98.92 \%)$ and the $\Phi S T$ value was $0.0108(p=0.006)$.

In addition, the mean Tajima's $D$ and Fu's $F$ s values over all samples and three localities (e.g., NS, YS, and LD) were negative, indicating a deviation from neutrality with population expansion (Table 1). Mismatch distribution analysis of all samples of $H$. oxycephalus revealed a unimodal shape. The sum of squared deviation (SSD) and Harpending's raggedness index (RI) were not significant $(\mathrm{SSD}=0.0076, p=0.349 ; \mathrm{RI}=0.0221, p=0.514)$, which indicates that the observed results fit with the growth expansion model (Figure 3). Both group I and group II showed similar results for the mismatch distribution analysis with the whole group of $H$. oxycephalus (Table 1). The Bayesian skyline plot for total $H$. oxycephalus revealed Pleistocene demographic expansion,
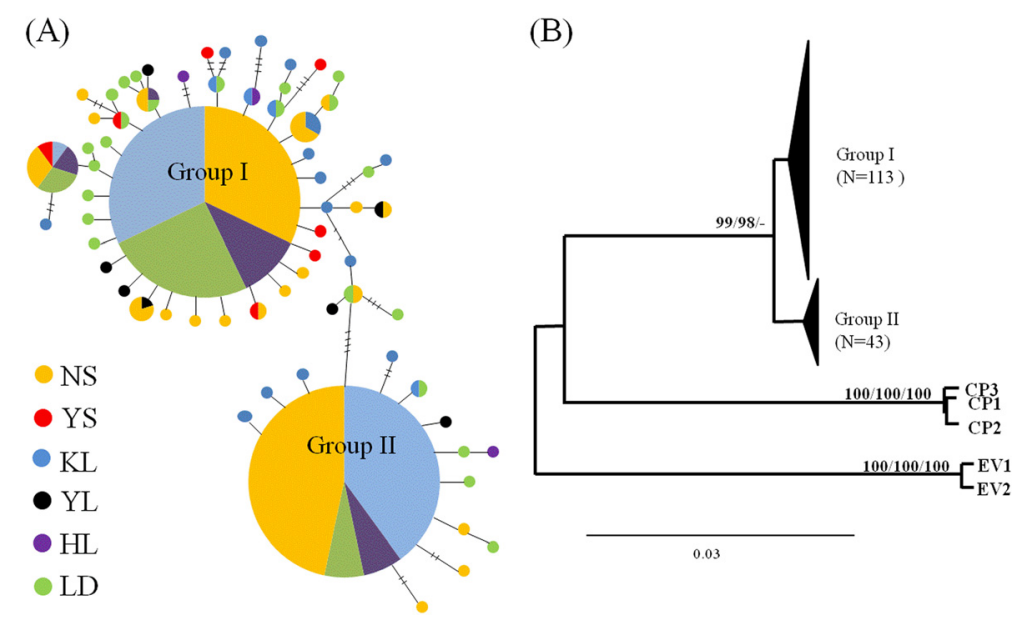

Figure 2 Minimum spanning network and phylogenetic tree of Hirundichthys oxycephalus from the northwestern Pacific. (A) Minimum spanning network among haplotypes. Each circle represents a unique haplotype, and the diameter is proportional to the individual number sharing that haplotype. Different colors stand for different sampling localities (NS, Nagasaki; YS, Yakushima; KL, Keelung; YL, Yilan; HL, Hualien; LD, Ludao). (B) Phylogenetic tree based on neighbor-joining analysis. Topologies of Bayesian and maximum parsimony analyses are similar, but group I is not recovered. Numbers above nodes are support values of neighbor-joining, Bayesian, and maximum parsimony, respectively. Only values over 50 are shown. (Number of individuals of each locality in group I: $N S=36, Y S=8, K L=25, Y L=6, H L=9, L D=29$; number of individuals of each locality in group II: NS = 18, KL=16, $\mathrm{YL}=1, \mathrm{HL}=3, \mathrm{LD}=5$ ). 
Table 2 Genetic structure of Hirundichthys oxycephalus population based on mtDNA COI gene

\begin{tabular}{|c|c|c|c|c|c|}
\hline $\begin{array}{l}\text { Source of } \\
\text { variation }\end{array}$ & $d f$ & $\begin{array}{l}\text { Sum of } \\
\text { squares }\end{array}$ & $\begin{array}{l}\text { Variance } \\
\text { components }\end{array}$ & $\begin{array}{l}\text { Percentage } \\
\text { of variation }\end{array}$ & $\begin{array}{l}\text { Fixation } \\
\text { index, } \Phi\end{array}$ \\
\hline Among groups & 1 & 0.753 & -0.0535 & -3.0613 & -0.0306 \\
\hline $\begin{array}{l}\text { Among } \\
\text { populations } \\
\text { within groups }\end{array}$ & 4 & 12.387 & 0.0723 & 4.1397 & $0.0402^{*}$ \\
\hline $\begin{array}{l}\text { Within } \\
\text { populations }\end{array}$ & 151 & 259.206 & 1.7280 & 98.9216 & $0.0108^{*}$ \\
\hline
\end{tabular}

${ }^{*} p<0.05$.

which occurred between 40,000 and 140,000 years ago (Figure 4). TMRCA for total $H$. oxycephalus was 0.531 million years ago (HPD 95\% confidence interval was 0.317 to 0.743 million years ago).

The neighbor-joining tree (Figure 2B) showed that the haplotypes of $H$. oxycephalus were divided into two groups with high bootstrap value but low genetic distance $(0.9 \%)$. Despite varying in abundance, haplotypes from most localities were shared by the two groups, with the exception that those from YS were only present in group I. Bayesian and maximum parsimony trees showed similar topology, but group I was not recovered in these two analyses.

\section{Discussion}

In this study, we used a 616-bp fragment of the mtDNA COI gene to analyze the population genetic structure of $H$. oxycephalus. The mean haplotype diversity of the six localities was high, but nucleotide diversity was low (Table 1). Marine fish populations can be classified into four categories according to the different combinations of values for nucleotide diversity and haplotype diversity (Grant and Bowen 1998). In $H$. oxycephalus, the high nucleotide diversity and low haplotype diversity seem to

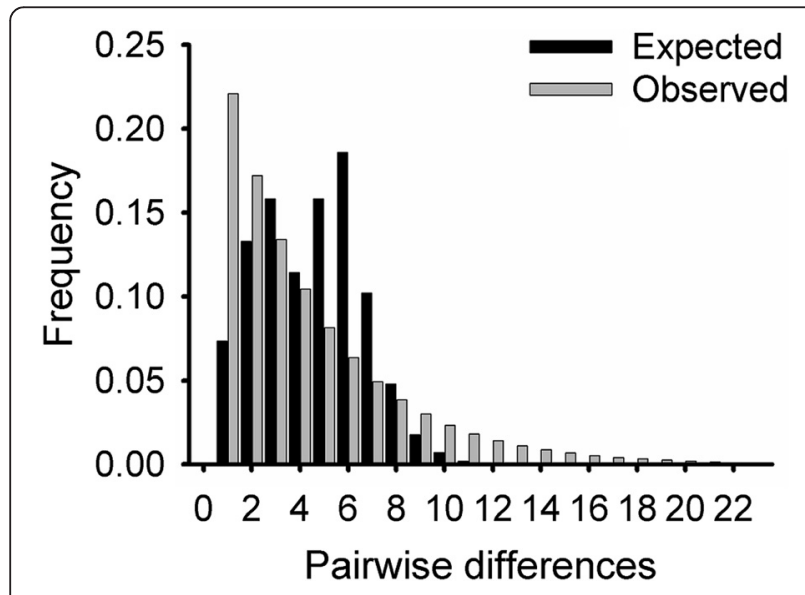

Figure 3 Mismatch distribution of Hirundichthys oxycephalus in the northwestern Pacific.

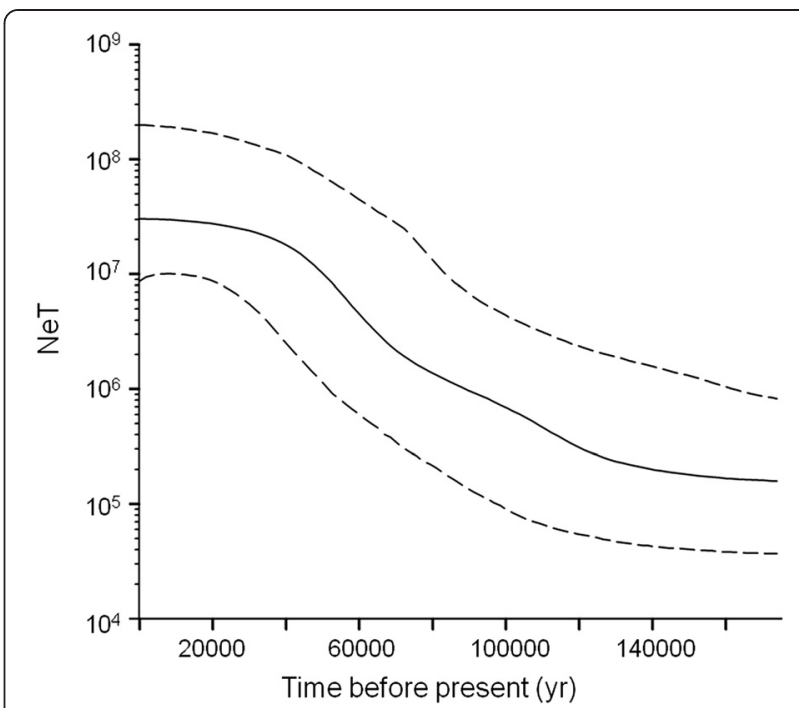

Figure 4 Bayesian skyline plot for total Hirundichthys oxycephalus in the northwestern Pacific. The Bayesian skyline plot is derived from mtDNA COI sequences, where the $x$-axis is time in years and the $y$-axis is the product of effective population size ( $\mathrm{Ne}$ ) and generation time ( $T$ ). The black line indicates the median estimate, and dashed lines indicate the $95 \%$ highest posterior density (HPD) region.

fit the population of the second category, i.e., with a scenario of population bottleneck followed by a rapid population growth and accumulation of mutations. Negative and significant values of Tajima's $D$ and Fu's $F$ s tests, as well as the unimodal shape of mismatch distribution and the Bayesian skyline plot (Figure 3; Table 1), also support the above classification. During the last glacial maximum (LGM), the sea surface temperature was maximally $3^{\circ} \mathrm{C}$ cooler than it is today (Stott et al. 2002). The cooler temperature could have further limited the distribution of tropical and subtropical species, such as flyingfish, and thus eventually reducing the population size. The fit to an expansion model might be due to its recent colonization from warm refuge after Pleistocene cooling had occurred (Díaz-Jaimes et al. 2006). A similar episode was also observed among dolphinfish, yellowfin tuna, and whiskered velvet shrimp (Díaz-Jaimes et al. 2006; Dammannagoda et al. 2008; Chu et al. 2012).

According to the Bayesian skyline plot for $H$. oxycephalus, demographic expansion was estimated to occur during the Pleistocene period (Figure 4). Similar observations were noted for some marine fauna, such as mitten crab, mottled spinefoot, and ice goby in the western Pacific, whose Bayesian skyline plots also indicated that the populations had experienced Pleistocene demographic expansion ( $\mathrm{Xu}$ et al. 2009; Ravago-Gotanco and Juinio-Meñez 2010; Kokita and Nohara 2011). In addition, the TMRCA estimates for all samples of $H$. oxycephalus indicated that the expansion occurred approximately in the middle Pleistocene period, which is 
much later than the flathead mullet in this region which occurred in the early Pleistocene period or even in the Pliocene period (Shen et al. 2011).

The low genetic differentiation among six localities in the northwestern Pacific Ocean, along with the variation mostly found within populations rather than among them (AMOVA, Table 2), implies a high gene flow of $H$. oxycephalus among populations. The strong and constant Kuroshio Current might facilitate the gene flow of species distributed within the northwestern Pacific Ocean and result in a weak genetic structure (Hohenlohe 2004). This may account for the low genetic differentiation of $H$. oxycephalus and the other species distributed in the range of the Kuroshio Current, including albacore (Wu et al. 2009), Japanese eel (Han et al. 2010), Japanese anchovy (Liu et al. 2006), crocker (Han et al. 2008a,b), mackerel (Chiou and Lee 2004), mullet (Liu et al. 2007; Liu et al. 2009; Shen et al. 2011), goby (Iida et al. 2010; Ju et al. 2013), and whiskered velvet shrimp (Chu et al. 2012).

Historical and ecological factors may influence the demography of marine fishes and result in significant population structure (Riginos and Nachman 2001; Yu et al. 2002; Lourie and Vincent 2004; Liu et al. 2007). On the contrary, species with high dispersal potential and longer pelagic larval duration, such as bigeye tuna (Chiang et al. 2008), albacore (Wu et al. 2009), Atlantic mackerel (Nesbø et al. 2000), and billfish (Graves and McDowell 1995), tend to have high level of gene flow and a lack of population genetic structure (Palumbi 1994, 2003; Shulman 1998; Bohonak 1999; Planes et al. 2001; Purcell et al. 2006, 2009). Despite their distant dispersal and pelagic stage, $H$. affinis of the central western Atlantic can be divided into three lineages with distinct geographic distribution. Furthermore, its population genetic structure is considered to be associated with spawning behavior (Gomes et al. 1999). In the present study, phylogenetic trees and minimum spanning network of $H$. oxycephalus revealed two distinct clades with minor genetic distance. The subdivision implied that the specimens of $H$. oxycephalus were composed of two populations. However, the interrelationship of either stock to any sampling locality, the Kuroshio, or other minor currents was not detected. Similar results have also been observed in other marine fishes in the northwestern Pacific (Chiou and Lee 2004; Liu et al. 2007; Han et al. 2008a,b; Liu et al. 2009; Wu et al. 2009; Han et al. 2010; Iida et al. 2010; Shen et al. 2011; Chu et al. 2012; Ju et al. 2013), in which major ocean current patterns are not good predictors of gene flow. On the other hand, historical factors such as Pleistocene glaciations might account for the genetic pattern of $H$. oxycephalus. Further study that includes more comprehensive samplings throughout its distribution range would facilitate classification of the genetic pattern.
There are two major definitions for a biological population: the ecological definition that reflects mainly the co-occurrence and demographic interaction of individuals in time and space, and the evolutionary definition that is based on genetic structure due to reproductive interactions among individuals (Waples and Gaggiotti 2006; Reiss et al. 2009). If a significant and reproducible genetic differentiation can be detected, the populations could be considered as separate evolutionarily defined populations with demographical independence (Bentzen 1998). Accordingly, the present study suggested that genetically speaking, there were two populations of $H$. oxycephalus that existed in the studied region; however, the genetic differentiation was not 'significant' enough according to the results of the genetic analysis (Figure 2B).

On the other hand, the present study showed that the haplotypes from most localities were shared by the two groups with the exception of those from YS, which were only present in group I (Figure 2). There were only eight specimens available from YS for the present study, and the limited sample size might have inevitably introduced some uncertainties to the results of the analysis. YL, a locality with only seven specimens, also showed similar pattern, i.e., all haplotypes except one were placed in group I (Figure 2). Therefore, if temporarily ignoring samples with possible sampling bias, the results tended to suggest that the $H$. oxycephalus from eastern Taiwan and from western Japan was a single population. A separate 3-year study on the spatio-temporal distributions of fish density, body length, and gonadosomatic index (GSI) data of the fish from the same region also suggested one population in the region with two possible migration routes (SK Chang, CH Lin, S Jan, T Ichimaru, and $\mathrm{CE}$ Chou, unpublished data). These observations suggested that $H$. oxycephalus from the northwestern Pacific Ocean belonged to one ecologically defined population.

Fish populations are the fundamental biological unit. Ignoring the congruence of spatial scales between the population structure of fish species and management units can result in reduced productivity and local reduction of population (Kenchington et al. 2003; Waples and Gaggiotti 2006; Worm et al. 2006). Currently, the only known spawning ground of $H$. oxycephalus is north of Taiwan (Chang et al. 2012b). The spawning activities of the fish take place from May to July, which is the major spawning season based on the back-calculation performed in a daily growth increments study (Chang et al. 2012a). A reproductive biology study on $H$. oxycephalus suggested that the fish was a batch spawner with asynchronous oocyte development patterns $(\mathrm{CH}$ Lin, YT Tsuei, and SK Chang, unpublished data). Based on the assumption of one ecological population, there might be another unknown distinct spawning ground for the same population during the second spawning season in winter 
time. Currently, there are no implemented management measures on this species in Japan, and the measures implemented by Taiwan are only for flyingfish egg fishery in eastern Taiwan. Although the hypothesis of either one or two populations has not been confirmed, it is evident that the current management scheme covering only the eastern waters of Taiwan mismatches with the spatial structure of the biological population. To properly and effectively manage the resource of $H$. oxycephalus, negotiations and joint efforts between the Taiwanese and Japanese governments are needed.

\section{Conclusions}

Study of population structures is a significant step toward realizing the goal of management of fishery and conservation of the fish resources in their natural population (Abdul-Muneer 2014). This approach has been previously applied to $H$. affinis in the central western Atlantic (Gomes et al. 1999). To our knowledge, this is the first study to investigate the population genetics of flyingfish in the northwestern Pacific Ocean, particularly with a focus on an economically valuable species, $H$. oxycephalus, distributed among East Asian countries (Shao 2009). Neutrality tests and mismatch distribution analysis based on the fragment of the mtDNA COI gene of $H$. oxycephalus collected from the northwestern Pacific Ocean suggested that $H$. oxycephalus was undergoing population expansion, probably due to recent colonization from warm refuge after Pleistocene cooling (Díaz-Jaimes et al. 2006). AMOVA showed that most variation was within populations, implying that high gene flow of $H$. oxycephalus occurred among populations, which was probably facilitated by the Kuroshio Current. Phylogenetic analyses and minimum spanning network showed that the fish were genetically divided into two groups. However, the genetic divergence between the two groups was low, and the separation was not geologically evident. On the other hand, based on the genetic data of the present study, which is supported by an independent ecological study (SK Chang, CH Lin, $\mathrm{S}$ Jan, T Ichimaru, and CE Chou, unpublished data), $H$. oxycephalus from eastern Taiwan and from northwestern Japan might be considered as one population. Effective fishery management of $H$. oxycephalus requires joint efforts from countries within its population boundary in order to maintain sustainable exploitation.

\section{Competing interests}

The authors declare that they have no competing interests.

\section{Authors' contributions}

CEC conducted the analyses and prepared the draft. TYL provided the technical text and discussion and made contributions equal to those of CEC. HWC commented on and edited the draft. SKC provided the idea for the study and text on fisheries, management and conclusions and edited the manuscript. SKC is also the primary corresponding author of this manuscript. All authors read and approved the final manuscript.

\section{Acknowledgements}

The authors are thankful for the special efforts from Mr. Chung-Hui Lin in fish sampling and Mr. Tsung-Wei Lin in molecular analysis. Constructive comments from Dr. Tzong-Der Tzeng of the Shu-Te University on the early work and from the two anonymous reviewers on the manuscript are much appreciated. This study was financially supported by the Ministry of Science and Technology (NSC99-2611-M-110-017, NSC100-2611-M-1 10-016, and NSC101-2611-M-110013) and partially by the Asia-Pacific Ocean Research Centre, National Sun Yat-sen University.

\section{Author details}

'Department of Biological Sciences, National Sun Yat-sen University, 70, Lien-hai Road, Kaohsiung 804, Taiwan. ${ }^{2}$ Department of Oceanography, National Sun Yat-sen University, 70, Lien-hai Road, Kaohsiung 804, Taiwan. ${ }^{3}$ Institute of Marine Affairs, National Sun Yat-sen University, 70, Lien-hai Road, Kaohsiung 804, Taiwan.

Received: 16 May 2014 Accepted: 10 December 2014 Published online: 16 January 2015

\section{References}

Abdul-Muneer PM (2014) Application of microsatellite markers in conservation genetics and fisheries management: recent advances in population structure analysis and conservation strategies. Genet Res Int 2014:11, doi:10.1155/2014/ 691759

Bentzen P (1998) Seeking evidence of local stock structure using molecular genetic methods. In: Herbing IH, Kornfield I, Tupper M, Wilson J (eds) The implications of localized fisheries stocks. Regional Agricultural Engineering Service, New York, pp 20-30

Bermingham E, McCafferty SS, Martin PP (1997) Fish biogeography and molecular clocks: perspectives from the Panamian Isthmus. In: Stepien CA (ed) Kocher TD. Molecular Systematics of Fishes, San Diego, pp 113-228

Bohonak AJ (1999) Dispersal, gene flow, and population structure. Q Rev Biol 74(1):21-45

Chang CW, Lin CH, Chen YS, Chen MH, Chang SK (2012a) Age validation, growth estimation and cohort dynamics of the bony flying fish Hirundichthys oxycephalus off eastern Taiwan. Aquat Biol 15(3):251-260, doi:10.3354/ ab00425

Chang SK, Chang CW, Ame E (2012b) Species composition and distribution of the dominant flyingfishes (Exocoetidae) associated with the Kuroshio Current, South China Sea. Raffles Bull Zool 60(2):539-550

Chiang HC, Hsu CC, Wu GCC, Chang SK, Yang HY (2008) Population structure of bigeye tuna (Thunnus obesus) in the Indian Ocean inferred from mitochondrial DNA. Fish Res 90(1-3):305-312, doi:10.1016/j.fishres.2007.11.006

Chiou WD, Lee LK (2004) Migration of kawakawa Euthynnus affinis in the waters near Taiwan. Fish Sci 70(5):746-757, doi:10.1111/j.1444-2906.2004.00867.x

Chu TJ, Wang D, Huang HL, Lin FJ, Tzeng TD (2012) Population structure and historical demography of the whiskered velvet shrimp (Metapenaeopsis barbata) off China and Taiwan inferred from the mitochondrial control region. Zool Stud 51(1):99-107

Cumberbatch JA, Hinds CJ (2013) Barbadian bio-cultural heritage: an analysis of the flying fish. Int J Intangible Heritage 8:118-134

Dammannagoda ST, Hurwood DA, Mather PB (2008) Evidence for fine geographical scale heterogeneity in gene frequencies in yellowfin tuna (Thunnus albacares) from the north Indian Ocean around Sri Lanka. Fish Res 90(1-3):147-157, http://dx.doi.org/10.1016/j.fishres.2007.10.006

Davenport J (1994) How and why do flying fish fly? Rev Fish Biol Fish 4(2):184-214, doi:10.1007/BF00044128

Díaz-Jaimes P, Uribe-Alcocer M, Ortega-García S, Durand JD (2006) Spatial and temporal mitochondrial DNA genetic homogeneity of dolphinfish populations (Conphaena hippurus) in the eastern central Pacific. Fish Res 80(2-3):333-338, doi:10.1016/j.fishres.2006.04.015

Drummond AJ, Rambaut A (2007) BEAST: Bayesian evolutionary analysis by sampling trees. BMC Evol Biol 7:214, doi:10.1186/1471-2148-7-214

Excoffier L, Lischer HEL (2010) Arlequin suite ver 3.5: a new series of programs to perform population genetics analyses under Linux and Windows. Mol Ecol Resour 10(3):564-567, doi:10.1111/j.1755-0998.2010.02847.x 
Excoffier L, Smouse PE, Quattro JM (1992) Analysis of molecular variance inferred from metric distances among DNA haplotypes: application to human mitochondrial DNA restriction data. Genetics 131(2):479-491

Felsenstein J (1985) Confidence limits on phylogenies: an approach using the bootstrap. Evolution 39:783-791, doi:10.2307/2408678

Fisheries Agency (2010) Fisheries statistical yearbook - Taiwan, Kinmen and Matsu Area, 2009. Fisheries Agency, Council of Agriculture, Taipei

Fu YX (1997) Statistical tests of neutrality of mutations against population growth, hitchhiking and background selection. Genetics 147(2):915-925

Garcia SM (2005) Fisheries and aquaculture topics. Defining fishery stocks. Topics Fact Sheets. FAO Fisheries and Aquaculture Department [online]. http://www.fao.org/fishery/topic/14787/en. Accessed 23 April 2014

Goloboff PA, Farris JS, Nixon KC (2008) TNT, a free program for phylogenetic analysis. Cladistics 24(5):774-786, doi:10.1111/j.1096-0031.2008.00217.x

Gomes C, Dales RBG, Oxenford HA (1998) The application of RAPD markers in stock discrimination of the four-wing flyingfish, Hirundichthys affinis in the central western Atlantic. Mol Ecol 7(8):1029-1039, doi:10.1046/j.1365-294x.1998.00427.x

Gomes C, Oxenford HA, Dales RBG (1999) Mitochondrial DNA D-loop variation and implications for stock structure of the four-wing flyingfish, Hirundichthys affinis, in the central western Atlantic. Bull Mar Sci 64(3):485-500

Gomes C, Oxenford HA, Dales RBG (2000) Restriction site mapping of the mitochondrial DNA of the four-wing flyingfish, Hirundichthys affinis. Mitochondr DNA 11(3):277-280, doi:10.3109/10425170009033243

Grant W, Bowen B (1998) Shallow population histories in deep evolutionary lineages of marine fishes: insights from sardines and anchovies and lessons for conservation. J Hered 89(5):415-426, doi:10.1093/jhered/89.5.415

Graves JE, McDowell JR (1995) Inter-ocean genetic divergence of istiophorid billfishes. Mar Biol 122(2):193-203, doi:10.1007/BF00348932

Hall TA (1999) BioEdit: a user-friendly biological sequence alignment editor and analysis program for Windows 95/98/NT. Nucleic Acids Symp Ser 41:95-98, doi:citeulike-article-id:691774

Han ZQ, Gao TX, Yanagimoto T, Sakurai Y (2008a) Deep phylogeographic break among white croaker Pennahia argentata (Sciaenidae, Perciformes) populations in North-western Pacific. Fish Sci 74(4):770-780, doi:10.1111/ j.1444-2906.2008.01588.x

Han ZQ, Gao TX, Yanagimoto T, Sakurai Y (2008b) Genetic population structure of Nibea albiflora in Yellow Sea and East China Sea. Fish Sci 74(3):544-552, doi:10.1111/j.1444-2906.2008.01557.x

Han YS, Hung CL, Liao YF, Tzeng WN (2010) Population genetic structure of the Japanese eel Anguilla japonica: panmixia at spatial and temporal scales. Mar Ecol Prog Ser 401:221-232, doi:10.3354/meps08422

Harpending HC (1994) Signature of ancient population growth in a lowresolution mitochondrial DNA mismatch distribution. Hum Biol 66(4):591-600

Hohenlohe PA (2004) Limits to gene flow in marine animals with planktonic larvae: models of Littorina species around Point Conception, California. Biol J Linn Soc 82(2):169-187, doi:10.1111/j.1095-8312.2004.00318.x

Ichimaru T (2007) The life cycle of three species of flyingfish in the north waters of Kyusyu and the recruitment of young flyingfish to the fishing ground. Bull Nagasaki Prefectural Inst Fisheries 33:7-110

lida M, Zenimoto K, Watanabe S, Kimura S, Tsukamoto K (2010) Larval transport of the amphidromous goby Sicyopterus japonicus by the Kuroshio Current. Coast Mar Sci 34:42-46

Ju YM, Hsu CH, Fang LS, Lin HD, Wu JH, Han CC, Chen IS, Chiang TY (2013) Population structure and demographic history of Sicyopterus japonicus (Perciformes; Gobiidae) in Taiwan inferred from mitochondrial control region sequences. Genet Mol Res 12:4046-4059, doi:10.4238/2013

Kenchington E, Heino M, Nielsen EE (2003) Managing marine genetic diversity: time for action? ICES J Mar Sci: J Conseil 60(6):1172-1176, doi:10.1016/s1054-3139(03) 00136-x

Kokita T, Nohara K (2011) Phylogeography and historical demography of the anadromous fish Leucopsarion petersii in relation to geological history and oceanography around the Japanese Archipelago. Mol Ecol 20:143-164, doi:10.1111/j.1365-294X.2010.04920.x

Kutschera U (2005) Predator-driven macroevolution in flyingfishes inferred from behavioural studies: historical controversies and a hypothesis. Ann Hist Phil Biol 10:59-77

Lewallen EA, Pitman RL, Kjartanson SL, Lovejoy NR (2011) Molecular systematics of flyingfishes (Teleostei: Exocoetidae): evolution in the epipelagic zone. Biol J Linn Soc 102(1):161-174, doi:10.1111/j.1095-8312.2010.01550.X

Liu JX, Gao TX, Zhuang ZM, Jin XS, Yokogawa K, Zhang YP (2006) Late Pleistocene divergence and subsequent population expansion of two closely related fish species, Japanese anchovy (Engraulis japonicus) and Australian anchovy (Engraulis australis). Mol Phylogenet Evol 40(3):712-723, doi:10.1016/ j.ympev.2006.04.019

Liu JX, Gao TX, Wu SF, Zhang YP (2007) Pleistocene isolation in the Northwestern Pacific marginal seas and limited dispersal in a marine fish, Chelon haematocheilus (Temminck \& Schlegel, 1845). Mol Ecol 16(2):275-288, doi:10.1111/j.1365-294X.2006.03140.x

Liu JY, Brown CL, Yang TB (2009) Population genetic structure and historical demography of grey mullet, Mugil cephalus, along the coast of China, inferred by analysis of the mitochondrial control region. Biochem Syst Ecol 37(5):556-566, http://dx.doi.org/10.1016/j.bse.2009.09.002

Lourie SA, Vincent ACJ (2004) A marine fish follows Wallace's Line: the phylogeography of the three-spot seahorse (Hippocampus trimaculatus, Syngnathidae, Teleostei) in Southeast Asia. J Biogeogr 31(12):1975-1985, doi:10.1111/j.1365-2699.2004.01153.x

Masuda H, Amaoka K, Araga C, Uyeno T, Yoshino T (1984) The fishes of the Japanese archipelago. Tokai University Press, Tokyo

Nelson JS (2006) Fishes of the world, 4th edn. John Wiley \& Sons, Inc., New York

Nesbø CL, Rueness EK, Iversen SA, Skagen DW, Jakobsen KS (2000) Phylogeography and population history of Atlantic mackerel (Scomber scombrus L.): a genealogical approach reveals genetic structuring among the eastern Atlantic stocks. Proc R Soc Biol Sci Ser B 267(1440):281-292

Nylander JAA (2004) MrModeltest v2. Program distributed by the author. Evolutionary Biology Centre, Uppsala University. doi:citeulike-articleid: 7578084

Oxenford HA, Hunte W (1999) Feeding habits of the dolphinfish (Coryphaena hippurus) in the eastern Caribbean. Sci Mar 63:303-315, doi:10.3989/ scimar.1999.63n3-4317

Palumbi SR (1994) Genetic divergence, reproductive isolation, and marine speciation. Annu Rev Ecol Syst 25(1):547-572, doi:10.1146/annurev.es.25.110194.002555

Palumbi SR (2003) Population genetics, demographic connectivity, and the design of marine reserves. Ecol Appl 13(sp1):146-158, doi:10.1890/1051-0761 (2003)013[0146:PGDCAT]2.0.CO;2

Planes S, Doherty PJ, Bernardi G (2001) Strong genetic divergence among populations of a marine fish with limited dispersal, Acanthochromis polyacanthus, within the Great Barrier Reef and the Coral Sea. Evolution 55(11):2263-2273, doi:10.1111/j.0014-3820.2001.tb00741.x

Potts AC, Thomas AD, Nichols E (2003) An economic and social assessment of the flying fish (pelagic) fishery of Tobago, Trinidad and Toba. Proc Gulf Caribb Fish Inst 54:635-649

Purcell JFH, Cowen RK, Hughes CR, Williams DA (2006) Weak genetic structure indicates strong dispersal limits: a tale of two coral reef fish. Proc R Soc Biol Sci Ser B 273(1593):1483-1490, doi:10.1098/rspb.2006.3470

Purcell JFH, Cowen RK, Hughes CR, Williams DA (2009) Population structure in a common Caribbean coral-reef fish: implications for larval dispersal and early lifehistory traits. J Fish Biol 74(2):403-417, doi:10.1111/j.1095-8649.2008.02078.x

Rambaut A, Drummond A (2003) Tracer: a program for analysing results from Bayesian MCMC programs such as BEAST \& MrBayes. http://tree.bio.ed.ac.uk/ software/tracer. Accessed 18 April 2013

Ravago-Gotanco RG, Juinio-Meñez MA (2010) Phylogeography of the mottled spinefoot Siganus fuscescens: Pleistocene divergence and limited genetic connectivity across the Philippine archipelago. Mol Ecol 19:4520-4534, doi:10.1111/j.1365-294X.2010.04803.x

Reiss H, Hoarau G, Dickey-Collas M, Wolff WJ (2009) Genetic population structure of marine fish: mismatch between biological and fisheries management units. Fish Fisheries 10(4):361-395, doi:10.1111/j.1467-2979.2008.00324.x

Rennie J (2002) Review of the social and economic status of the flyingfish fishery in Grenada. In: FAO/WECAFC (ed) Report on the second meeting of the WECAFC Ad Hoc Flyingfish Working Group of the Eastern Caribbean. Bridgetown, Barbados, 8-12 January 2001. FAO Fisheries Report No. 670, 156 pp., FAO, Rome, pp 103-157

Riginos C, Nachman MW (2001) Population subdivision in marine environments: the contributions of biogeography, geographical distance and discontinuous habitat to genetic differentiation in a blennioid fish, Axoclinus nigricaudus. Mol Ecol 10(6):1439-1453, doi:10.1046/j.1365-294X.2001.01294.x

Ronquist F, Teslenko M, van der Mark P, Ayres DL, Darling A, Höhna S, Larget B, Liu L, Suchard MA, Huelsenbeck JP (2012) MrBayes 3.2: efficient Bayesian phylogenetic inference and model choice across a large model space. Syst Biol 61:539-542, doi:10.1093/sysbio/sys029

Shao KT (2009) Taiwan fish database (web electronic publication). http://fishdb. sinica.edu.tw. http://fishdb.sinica.edu.tw. Accessed 10 Dec 2013 
Shen KN, Jamandre BW, Hsu CC, Tzeng WN, Durand JD (2011) Plio-Pleistocene sea level and temperature fluctuations in the northwestern Pacific promoted speciation in the globally-distributed flathead mullet Mugil cephalus. BMC Evol Biol 11(1):83-83, doi:10.1186/1471-2148-11-83

Shulman MJ (1998) What can population genetics tell us about dispersal and biogeographic history of coral-reef fishes? Aust J Ecol 23(3):216-225, doi:10.1111/j.1442-9993.1998.tb00723.x

Stott L, Poulsen C, Lund S, Thunell R (2002) Super ENSO and global climate oscillations at millennial time scales. Science 297(5579):222-226, doi:10.1126/ science. 1071627

Tajima F (1989) Statistical method for testing the neutral mutation hypothesis by DNA polymorphism. Genetics 123(3):585-595

Tamura K, Peterson D, Peterson N, Stecher G, Nei M, Kumar S (2011) MEGA5: molecular evolutionary genetics analysis using maximum likelihood evolutionary distance, and maximum parsimony methods. Mol Biol Evol 28:2731-2739, doi:10.1093/molbev/msr121

Waples RS, Gaggiotti O (2006) What is a population? An empirical evaluation of some genetic methods for identifying the number of gene pools and their degree of connectivity. Mol Ecol 15(6):1419-1439, doi:10.1111/j.1365294X.2006.02890.X

Ward RD (2000) Genetics in fisheries management. Hydrobiologia 420(1):191-201, doi:10.1023/A:1003928327503

Ward RD, Zemlak TS, Innes BH, Last PR, Hebert PDN (2005) DNA barcoding Australia's fish species. Philos Trans R Soc Lond B Biol Sci 360(1462):1847-1857, doi:10.1098/rstb.2005.1716

Worm B, Barbier EB, Beaumont N, Duffy JE, Folke C, Halpern BS, Jackson JBC, Lotze HK, Micheli F, Palumbi SR, Sala E, Selkoe KA, Stachowicz JJ, Watson R (2006) Impacts of biodiversity loss on ocean ecosystem services. Science 314 (5800):787-790, doi:10.1126/science.1132294

Wu CC, Lin JC, Su WC (2006) Diet and feeding habits of dolphin fish (Coryphaena hippurus) in the waters off eastern Taiwan. J Taiwan Fish Res 14(1):13-27

Wu GC-C, Chiang H-C, Chen K-S, Hsu C-C, Yang H-Y (2009) Population structure of albacore (Thunnus alalunga) in the Northwestern Pacific Ocean inferred from mitochondrial DNA. Fish Res 95(1):125-131, doi:10.1016/j.fishres.2008.07.014

Wu GC-C, Chiang H-C, Chou Y-W, Wong Z-R, Hsu C-C, Chen C-Y, Yang H-Y (2010) Phylogeography of yellowfin tuna (Thunnus albacares) in the Western Pacific and the Western Indian Oceans inferred from mitochondrial DNA. Fish Res 105(3):248-253, doi:10.1016/j.fishres.2010.03.015

Xu J, Chan T, Tsang LM, Chu KH (2009) Phylogeography of the mitten crab Eriocheir sensu stricto in East Asia: Pleistocene isolation, population expansion and secondary contact. Mol Phylogenet Evol 52:45-56, doi:10.1016/j. ympev.2009.02.007

Xu GH, Zhao LJ, Gao KQ, Wu FX (2013) A new stem-neopterygian fish from the Middle Triassic of China shows the earliest over-water gliding strategy of the vertebrates. Proc R Soc Biol Sci Ser B 280(1750):20122261, doi:10.1098/ rspb.2012.2261

Yu H-T, Lee Y-J, Huang S-W, Chiu T-S (2002) Genetic analysis of the populations of Japanese anchovy (Engraulidae, Engraulis japonicus) using microsatellite DNA. Mar Biotechnol 4(5):471-479, doi:10.1007/s10126-002-0035-8

\section{Submit your manuscript to a SpringerOpen ${ }^{\circ}$ journal and benefit from:}

- Convenient online submission

- Rigorous peer review

- Immediate publication on acceptance

- Open access: articles freely available online

- High visibility within the field

- Retaining the copyright to your article

Submit your next manuscript at $\gg$ springeropen.com 